\title{
Transmission electron microscopy of percutaneous fine needle aspirates from lung: a study of 70 cases
}

\author{
D C DAVIES, A J RUSSELL, R TAYAR, N T COOKE, M M LEVENE
}

From the Regional Cell Pathology Service, Wandle Valley Hospital, Mitcham Junction, Surrey, and Departments of Radiology and Medicine, St Helier Hospital, Carshalton, Surrey

ABSTRACT Seventy consecutive lüng fine needle aspirates (FNA) from 69 patients were examined by cytology/cell block histology, by transmission electron microscopy (TEM), and, where available, at $\%$ histological follow up to determine the value of TEM in interpreting lung FNAs. Of 70 FNAs, 50응 were suitable for TEM. Transmission electron microscopy was helpful in classifying seven of $10-$ poorly differentiated tumours, and two case histories are reported. In 26 of 30 well differentiatedo tumours TEM confirmed diagnosis by light microscopy. Two TEM false negatives, but no TEM false positives, were recorded. It is concluded that transmission electron microscopy of cells aspi- $-\vec{\infty}^{\circ}$ rated from lung can be helpful when unequivocal diagnosis has not been achieved.

Percutaneous fine needle aspiration (FNA) biopsy methods are widely used in the investigation of lung disease. $^{12}$ Aspirated specimens are examined cytologically or, less commonly, embedded for cell block histology. ${ }^{3-6}$ Methods for processing FNAs for transmission electron microscopy (TEM) have also been reported with good results, ${ }^{7-12}$ but TEM is not widely used, despite its apparent value in the diagnosis of lung disease. ${ }^{13-16}$

Specific diagnosis of cells aspirated from lung is vital as it largely determines treatment, ${ }^{17-21}$ but to our knowledge there has been only one publication that offers a detailed examination of the potential of TEM in interpreting lung FNAs. ${ }^{11}$ We report the results of 70 consecutive FNAs of lung examined by cytology and cell block histology, by TEM, and at follow up and assess the role of TEM in evaluating lung FNAs with particular reference to two case histories.

\section{Patients and methods}

From September 1983 to November 1985, 70 consecutive FNAs were performed on 69 patients. Patients were selected who had a lesion demonstrable by conventional radiography and computed tomography (CT) but normal or equivocal findings on

Address for reprint requests: Dr A J Russell, Regional Cell Pathology Service, Wandle Valley Hospital, Mitcham Junction, Surrey CR4 4XL.

Accepted 28 November 1986 sputum cytology and negative results from bron-ō choscopy and lavage.

Most biopsy examinations were carried out under $\stackrel{\odot}{\circ}$ dual image intensification, but for small lesions, $\vec{O}$ where lateral visualisation proved difficult, material 3 was best obtained under CT control. A range of needles was used, the best results being obtained with? the 22 gauge Franseen type. Pneumothorax occurred in about $10 \%$ of patients, and on two occasions a을 chest drain was necessary. No important haemoptysis occurred.

Aspirated material was expressed onto clean glass slides and tissue fragments removed and fixed for cello block histology and TEM. Smears made from the material that remained on the slides were either wet 9 fixed in $99 \%$ alcohol for Papanicolaou or $\frac{7}{8}$ haematoxylin and eosin staining or air dried and fixed in methanol for Romanowsky or periodic acid-SchiffN staining. For cell block histology, tissue fragments were fixed in $10 \%$ buffered formal saline, embedded in agar, wax processed, sectioned at $5 \mu \mathrm{m}$, and stained ${ }_{\sigma}^{\omega}$ with haematoxylin and eosin.

Tissue fragments were fixed for TEM in $1-2 \%$ phosphate buffered glutaraldehyde for $30-60 \AA$ minutes, post-fixed in $1 \%$ phosphate buffered osmium tetroxide, and embedded in epoxy resin. $\frac{T}{0}$ Smears from seven cases were fixed and processed by the "pop-off" technique. ${ }^{1022}$ One micron sections? were stained with toluidine blue to locate areas foro study. Ultrathin sections of these areas were stained with $3 \%$ alcoholic uranyl acetate and Reynolds' leado citrate and examined with an AEI EM6B trans 
mission electron microscope at $80 \mathrm{kV}$.

Smears and cell block preparations were examined to give an overall cytology/cell block histology assessment. TEM assessment was made without reference to cytology and cell block histology preparations or to follow up histology. The ultrastructural features of lung tumours used in diagnosis are defined elsewhere. ${ }^{101123-25}$ Follow up information was obtained in $\mathbf{4 2}$ cases from lung resection, necropsy, or observation of the natural history of the disease, and tumours were classified according to the 1981 classification of the World Health Organisation. ${ }^{26}$

\section{Results}

Table 1 shows the results of cytology/cell block histology and TEM. Of the 70 aspirates, 43 yielded positive results on cytology/cell block histology (tumour cells identified), five showed atypical features (suspicious but not obviously malignant cells present), 11 gave negative results (good sample, but no tumour or suspicious cells identified), and a further 11 aspirates were inadequate (poor sample with only blood, macrophages, or necrotic material present). Fifty specimens could be classified as positive, atypical, or negative by TEM. The remaining 20 were inadequate.

Table 2 compares diagnoses obtained by TEM, cytology/cell block histology, and follow up histology. Cytologically, the 50 cases suitable for TEM comprised 30 well differentiated tumours, 10 poorly differentiated tumours, three atypical cases, and seven
Table 1 Broad classification of 70 consecutive fine needle aspirates examined by cytology/cell block histology and by transmission electron microscopy

\begin{tabular}{|c|c|c|c|}
\hline $\begin{array}{l}\text { Classification from } \\
\text { cytology/cell block } \\
\text { histology }\end{array}$ & $\begin{array}{l}\text { No } \\
\text { of } \\
\text { cases }\end{array}$ & $\begin{array}{l}\text { Classification from } \\
\text { transmission electron } \\
\text { microscopy }\end{array}$ & $\begin{array}{l}\text { No } \\
\text { of } \\
\text { cases }\end{array}$ \\
\hline Positive & 43 & $\begin{array}{l}\text { Positive } \\
\text { Atypical } \\
\text { Negative } \\
\text { Inadequate }\end{array}$ & $\begin{array}{r}36 \\
4 \\
0 \\
3\end{array}$ \\
\hline Atypical & 5 & $\begin{array}{l}\text { Positive } \\
\text { Atypical } \\
\text { Negative } \\
\text { Inadequate }\end{array}$ & $\begin{array}{l}1 \\
0 \\
2 \\
2\end{array}$ \\
\hline Negative & 11 & $\begin{array}{l}\text { Positive } \\
\text { Atypical } \\
\text { Negative } \\
\text { Inadequate }\end{array}$ & $\begin{array}{l}2 \\
0 \\
2 \\
5 \\
4\end{array}$ \\
\hline Inadequate & 11 & $\begin{array}{l}\text { Positive } \\
\text { Atypical } \\
\text { Negative } \\
\text { Inadequate }\end{array}$ & $\begin{array}{r}4 \\
0 \\
0 \\
0 \\
11\end{array}$ \\
\hline Total & 70 & & 70 \\
\hline
\end{tabular}

negative cases. The seven "pop-off" specimens were all well differentiated tumours (six epidermoid and one small cell), and this diagnosis agreed with TEM diagnosis from tissue fragments.

There was good agreement between cytology/cell block histology, TEM, and follow up information in the 21 well differentiated epidermoid tumours, the diagnosis being confirmed in 19 by TEM and in 13 at follow up. Two cases were judged to be epidermoid by TEM but at follow up were considered to be

Table 2 Diagnosis in 50 fine needle aspirates in which material was adequate for transmission electron microscopy

\begin{tabular}{|c|c|c|c|c|c|c|}
\hline $\begin{array}{l}\text { Cytology/cell block } \\
\text { diagnosis }\end{array}$ & & $\begin{array}{l}\text { Transmission electron } \\
\text { microscopy diagnosis }\end{array}$ & & $\begin{array}{l}\text { Follow up } \\
\text { diagnosis }\end{array}$ & & $\begin{array}{l}\text { No follow up } \\
\text { available }\end{array}$ \\
\hline \multirow[t]{2}{*}{ Epidermoid carcinoma } & 21 & Epidermoid carcinoma & 19 & $\begin{array}{l}\text { Epidermoid carcinoma } \\
\text { Adenosquamous carcinoma } \\
\text { Undifferentiated carcinoma }\end{array}$ & $\begin{array}{r}13 \\
1 \\
1\end{array}$ & 4 \\
\hline & & $\begin{array}{l}\text { Adenosquamous carcinoma } \\
\text { Atypical }\end{array}$ & 1 & $\begin{array}{l}\text { Adenocarcinoma } \\
\text { Large cell carcinoma }\end{array}$ & $\begin{array}{l}1 \\
1\end{array}$ & \\
\hline Adenosquamous carcinoma & 1 & Adenosquamous carcinoma & 1 & Adenocarcinoma & 1 & \\
\hline Adenocarcinoma & 3 & $\begin{array}{l}\text { Adenocarcinoma } \\
\text { Atypical }\end{array}$ & $\begin{array}{l}2 \\
1\end{array}$ & Adenocarcinoma & & \\
\hline Small cell carcinoma & 4 & $\begin{array}{l}\text { Small cell carcinoma } \\
\text { Atypical }\end{array}$ & $\begin{array}{l}3 \\
1\end{array}$ & $\begin{array}{l}\text { Small cell carcinoma } \\
\text { Large cell carcinoma } \\
\text { Small cell carcinoma }\end{array}$ & $\begin{array}{l}2 \\
1 \\
1\end{array}$ & \\
\hline Chondrosarcoma & 1 & Chondrosarcoma & 1 & Chondrosarcoma & 1 & \\
\hline Undifferentiated carcinoma & 10 & $\begin{array}{l}\text { Epidermoid carcinoma } \\
\text { Adenosquamous carcinoma } \\
\text { Adenocarcinoma } \\
\text { Small cell carcinoma } \\
\text { Undifferentiated carcinoma } \\
\text { Atypical }\end{array}$ & $\begin{array}{l}3 \\
1 \\
1 \\
2 \\
2 \\
1\end{array}$ & $\begin{array}{l}\text { Epidermoid carcinoma } \\
\text { Adenocarcinoma } \\
\text { Small cell carcinoma } \\
\text { Metastatic carcinoma } \\
\text { Small cell carcinoma }\end{array}$ & $\begin{array}{l}1 \\
1 \\
2 \\
2 \\
1\end{array}$ & $\begin{array}{l}2 \\
1\end{array}$ \\
\hline Atypical & 3 & $\begin{array}{l}\text { Adenosquamous carcinoma } \\
\text { Negative }\end{array}$ & $\begin{array}{l}1 \\
2\end{array}$ & Negative & 2 & 1 \\
\hline Negative & 7 & $\begin{array}{l}\text { Atypical } \\
\text { Negative }\end{array}$ & $\begin{array}{l}2 \\
5\end{array}$ & $\begin{array}{l}\text { Epidermoid carcinoma } \\
\text { Negative } \\
\text { Large cell carcinoma }\end{array}$ & $\begin{array}{l}2 \\
3 \\
2\end{array}$ & \\
\hline Total & 50 & & 50 & & 42 & 8 \\
\hline
\end{tabular}




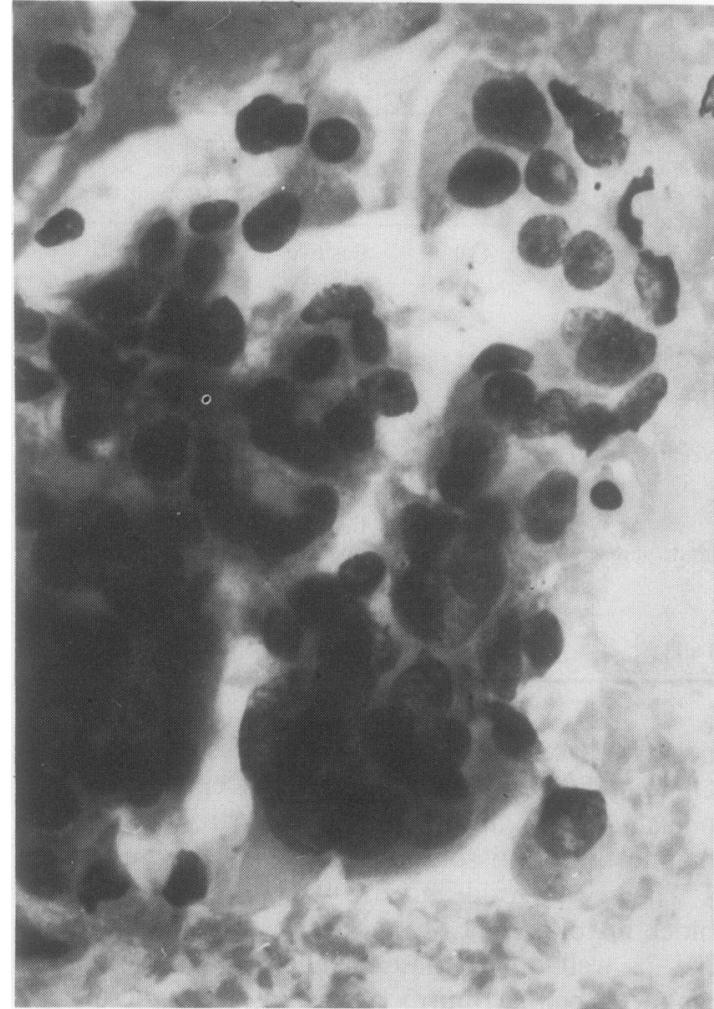

Fig 1 Cytological smear from case 1, with cells showing nuclear variation, coarse chromatin, and occasional nucleoli. (Haematoxylin and eosin.)

adenosquamous and undifferentiated carcinomas. No follow up material was available from four cases. One tumour, found to have an adenocarcinomatous element at TEM, was subsequently classified as adenocarcinoma. A further case was judged as atypical at TEM and as large cell carcinoma at follow up.

Agreement was fairly good in eight cases of well differentiated adenosquamous carcinoma, adenocarcinoma, and small cell carcinoma, although in two the TEM appearances were considered to be atypical rather than positive and one tumour initially classified as small cell later proved to be a large cell carcinoma. In the patient with chondrosarcoma cytology/cell block histology, TEM, and information obtained at follow up were in complete agreement.

TEM was helpful in the diagnosis of seven of the 10 undifferentiated tumours, and in four instances it was possible to confirm the diagnosis at follow-up. The value of TEM is illustrated further by reference to two of these examples as case reports (below). Of the three remaining undifferentiated tumours, two were classified as undifferentiated at TEM and untyped metastatic carcinomas at follow up and one was considered to be atypical at TEM and small cell at follow up.

Of three cases reported as atypical at cytology/cell block histology, one, without follow up, was? adenosquamous carcinoma at TEM and two were negative at TEM and at follow up. Of the seven cases $\frac{\rho}{\sigma}$ where results of cytology/cell block histology were $\_$ negative, two were considered to be atypical at TEM $\cong$ and epidermoid at follow up and two negative at $\vec{O}$ TEM but large cell at follow up (TEM false negatives). No TEM false positives were encountered.

\section{Case reports}

Case 1

A 65 year old woman presented with persistent cough and shortness of breath. She was a smoker and had $\circ$ diabetes and a history of bronchitis. A chest radio- $\frac{\text { ㅇ }}{-}$ graph showed shadowing in the left lower lobe. Cytology/cell block histology revealed pleomorphic, $\frac{7}{0}$ undifferentiated tumour cells with a homogenous cytoplasm, lying singly or in groups (Fig. 1). Nuclear $\vec{\oplus}$ variation was present, chromatin was coarse, and $\stackrel{\infty}{\vee}$ occasional nucleoli were seen. At TEM tumour cells 0

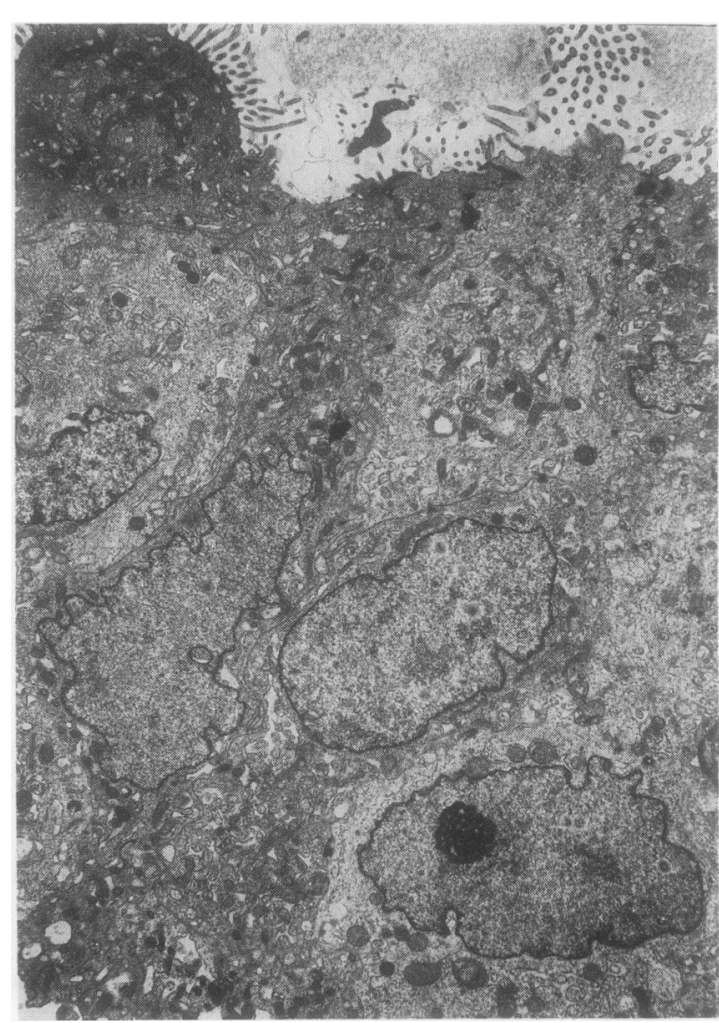

Fig 2 Transmission electron micrograph from case 1 .

Cells with apical microvilli, abundant cytoplasm with ribosomes and mitochondria, and large irregular nuclei with prominent nucleoli. 


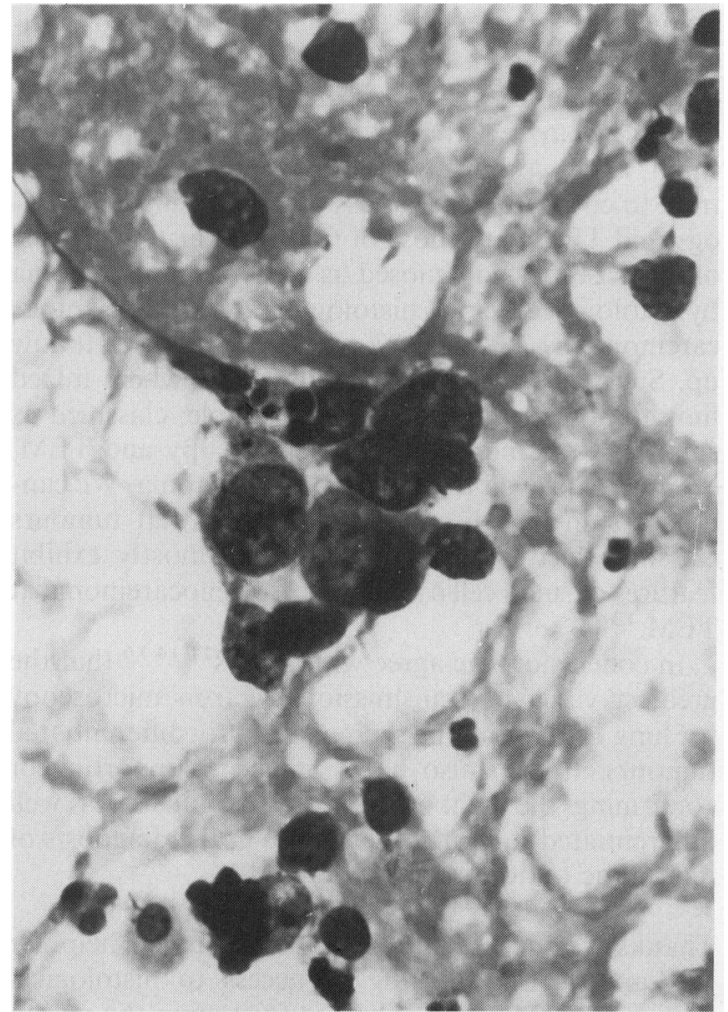

Fig 3 Cytological smear from case 2. Cells with little or no cytoplasm, showing nuclear variation, coarse chromatin, and occasional nucleoli. (Haematoxylin and eosin.)

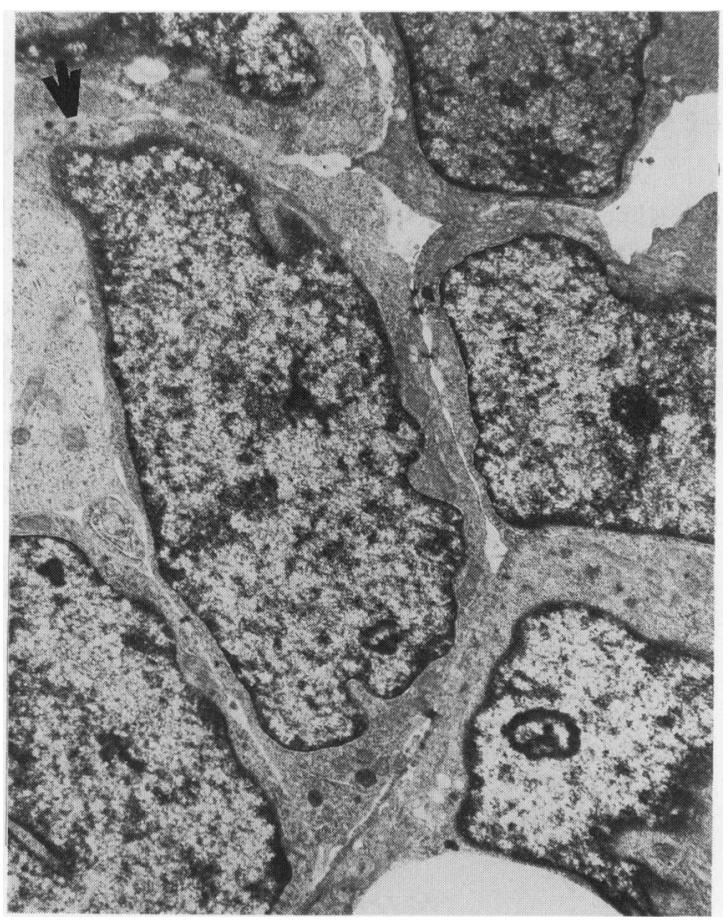

showed features of adenocarcinoma, with apical microvilli, abundant ribosomes, mitochondria, Golgi's corpuscles, accumulations of glycogen, and tight junctional complexes (Fig. 2). Nuclei were large, often with indented membranes, and nucleoli were prominent. Wedge resection of the apex of the left lower lobe revealed an adenocarcinoma $2 \mathrm{~cm}$ in diameter, with central necrosis and some papillary differentiation. The patient has since died.

\section{Case 2}

A 61 year old man, who had been a smoker for 45 years, presented with a four week history of weakness and numbness in the legs. A chest radiograph and computed tomogram revealed a $3 \mathrm{~cm}$ ill defined lesion in the left mid-zone. Bronchoscopy yielded normal results. The FNA, specimen contained poorly differentiated tumour cells at cytology/cell block histology (Fig. 3), lying singly or in groups, with little or no cytoplasm. Nuclei were pleomorphic, with coarse chromatin and occasional nucleoli. The TEM specimen contained cells consistent in appearance with small cell carcinoma (Fig. 4). There were occasional desmosomes and a scanty cytoplasm, with uncommon dense core granules. Nuclei were large and irregular, with coarse heterochromatin and prominent nucleoli. Bone marrow aspirates showed metastatic small cell carcinoma, and hepatic deposits were shown by ultrasound. The patient received chemotherapy but died one year later.

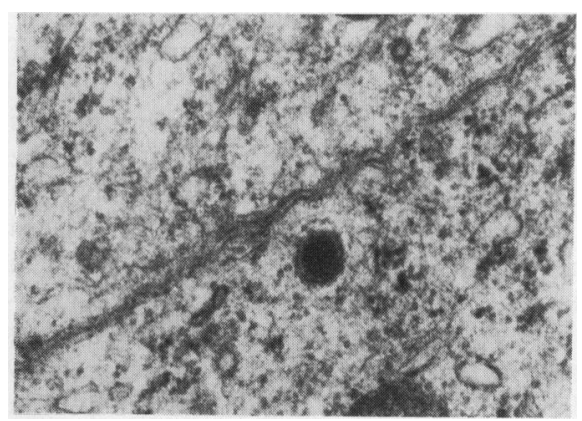

Fig 4 Transmission electron micrograph from case 2. Tumour cells attached by desmosomes, with a thin layer of cytoplasm surrounding irregular nuclei with prominent nucleoli. Occasional dense core granules (arrow) are present. Inset shows dense core granule at higher magnification. 


\section{Discussion}

There are few published ultrastructural studies of FNA derived lung material and there is little with which to compare our results. Two useful contributions are from Sehested and his coworkers, using pelleted aspirates, ${ }^{11}$ and from di Sant' Agnese, based on a modified "pop-off" technique. ${ }^{10}$

Like us, Sehested et al recorded one third of their consecutive aspirates unsuitable for TEM,${ }^{11}$ despite our using tissue fragments and, in a few cases, "popoff" specimens. Others have noted a greater proportion of aspirates suitable for TEM using a pelleting technique, ${ }^{14}$ although not all the material was derived from lung. The "pop-off" technique apparently increases the chances of locating suspicious cells. ${ }^{1022}$ We have not compared this technique critically with more traditional methods, but our limited observations suggest that preparation time is similar to that for tissue fragments, although embedding and cutting can be more demanding. In the few comparable cases we found tumour cells as quickly in tissue fragment blocks, but the "pop-off" method may be beneficial when such cells are scarce.

Sehested et al recorded full agreement between the results of cytology and TEM in all cases of well differentiated squamous cell carcinoma, small cell carcinoma and adenocarcinoma. ${ }^{11}$ We did not achieve such agreement, but our results were broadly similar. We agree with others that in cases where TEM does not significantly contribute to diagnosis its use may be unjustified. ${ }^{14-16}$ Specimens can, however, be held in glutaraldehyde as Berkman et al have advocated, ${ }^{14}$ so that TEM material can be prepared later if cytohistological diagnosis is not specific.

Although poor light microscopic differentiation is often paralleled at TEM, paradoxically it is in the classification of poorly differentiated tumours that TEM is most useful. ${ }^{1116}$ Poorly differentiated tumours may show features that aid diagnosis, such as tonofilaments, microvilli, dense core granules, ${ }^{1011151623-25}$ although these structures must be interpreted with caution as some are shared by several cell types. ${ }^{1627-29}$ We found TEM helpful in seven of 10 poorly differentiated cases, four of which were confirmed at follow up. This figure is different from that of Sehested et al (seven of eight with three confirmed at follow up), ${ }^{11}$ but their results, together with our two case reports, indicate the value of TEM diagnosis for poorly differentiated lung tumours. Some workers have reported the value of TEM in diagnosis of metastatic lesions, ${ }^{14}$ whereas others have found it of limited usefulness. ${ }^{18}$ In two cases of metastatic carcinoma in our study TEM was unhelpful in determining cell type or origin.

The major disadvantages of FNAs at light micro- scopy are sample size, sampling error, and variation, ${ }^{1-33031}$ and these also apply to TEM of FNA $\stackrel{9}{\stackrel{9}{9}}$ derived material. Large resected lung specimens, for example, may reveal a heterogeneity not apparent in $\frac{\bar{F}}{\bar{D}}$ small FNA specimens. ${ }^{29}$ For this reason we have $\frac{\rho}{\sigma}$ tried to compare, where possible, the results of cytol- $\stackrel{\mathbb{Q}}{\Omega}$ ogy and TEM with those of follow up histology. One of our cases wás diagnosed as epidermoid carcinoma $\vec{\circ}$ by cytology/cell block histology and adenosquamous carcinoma by TEM but as adenocarcinoma at follow $\vec{\omega}$ up. Such inconsistencies are inevitable where mixed lung tumours occur. A further example, classified as small cell carcinoma at light microscopy and TEM, $\vec{N}$ eventually proved to be large cell carcinoma. We cannot explain this discrepancy but note that tumours if classified histologically as large cell mostly exhibit features of small cell carcinoma or adenocarcinoma at $\stackrel{\circ}{\supset}$ TEM. ${ }^{13}$

In conclusion, we agree with others ${ }^{111416}$ that the $\frac{D}{O}$ greatest value of transmission electron microscopy for lung FNAs is in the typing of poorly differentiated $\vec{\oplus}$ tumours. It may also be of value in supporting or $\stackrel{\infty}{.}$ confirming the light microscopy diagnosis for well differentiated tumours, but its use in the diagnosis of metastatic tumours may be limited.

Thanks are due to Mrs J Ardley for technical help, Dr W Landells for allowing us access to histological reports, and Mrs B Blackmore for typing the manuscript.

\section{References}

1 Linsk JA, Franzen S. Clinical aspiration cytology. Philadelphia: J B Lippincott, 1983.

2 Koss LG, Woyke S, Olszewski W. Aspiration biopsy: cytologic interpretation and histological bases. New York: Igaku-Shoin, 1984.

3 Kline TS, Neal HS. Needle aspiration biopsy - a critical appraisal. Eight years and 3267 specimens later. 0 JAMA 1978;239:36-9.

4 Pilotti S, Rilke F, Gribandi G, Damascelli B. Fine needle $\frac{D}{O}$ aspiration biopsy cytology of primary and metastatic pulmonary tumours. Acta Cytol (Baltimore) N 1982;26:661-6.

5 Pilotti S, Rilke F, Gribandi G, Damascelli B, Ravasi G. 용 Transthoracic fine needle aspiration biopsy in pul- $\mathrm{W}$ monary lesions. Updated results. Acta Cytol (Baltimore) 1984;28:225-32.

6 Stevens GM, Jackman RJ. Outpatient needle biopsy of $\frac{0}{\frac{C}{(}}$ the lung: its safety and utility. Radiology 1984; 151:301-4.

7 Hagelqvist E. Light and electron microscopic studies on $\frac{T}{0}$ material obtained by fine needle biopsy. Acta Oto- $\frac{D}{\mathbb{D}}$ laryngol [Suppl] (Stockh) 1978;354:1-75.

8 Akhtar M, Ali MA, Owen EW, Bakry M. A simple method for processing fine needle aspiration biopsy specimens for electron microscopy. J Clin Pathol 1980;33:1214-6. 
9 Akhtar M, Ali MA, Owen EW. Application of electron microscopy in the interpretation of fine needle aspiration biopsies. Cancer 1981;48:2458-63.

10 di Sant' Agnese PA. Diagnostic electron microscopic and transthoracic fine needle biopsy. In: Bonfiglio TA, ed. Cytopathologic interpretation of transthoracic fine needle biopsies. New York: Masson Publishing, 1983:175-85.

11 Sehested M, Francis D, Hainan B. Electron microscopy of transthoracic fine needle aspiration biopsies. Acta Pathol Microbiol Immunol Scand [A] 1983; 91:457-61.

12 di'Sant Agnese PA, de Mesy Jensen KL, Bonfiglio TA, King DE, Patten SF. Plastic-embedded semi-thin sections of fine needle aspiration biopsies with dibasic staining. Acta Cytol (Baltimore) 1985;29:475-83.

13 Leong ASY. The relevance of ultrastructural examination in the classification of primary lung tumours. Pathology 1982;14:37-46.

14 Berkman WA, Chowdhury L, Brown NL, Padleckas R. Value of electron microscopy in cytologic diagnosis of fine needle biopsy. AJR 1983;140:1253-8.

15 Wang NS. Application of electron microscopy to diagnostic pulmonary pathology. Hum Pathol 1983;14:888-900.

16 Fisher C, Ramsay AD, Griffiths M, McDougall J. An assessment of the value of electron microscopy in tumour diagnosis. J Clin Pathol 1985;38:403-8.

17 Dahlgren S, Nordenstrom B. Transthoracic needle biopsy. Stockholm: Almqvist and Wiksell, 1966.

18 Payne CR, Stovin PGI, Barker V, McVittie S, Stark JE. Diagnostic accuracy of cytology and biopsy in primary bronchial carcinoma. Thorax 1979;34:294-9.

19 Thornbury JR, Burke DP, Naylor B. Transthoracic needle aspiration; accuracy of cytological typing of malignant neoplasm. AJR 1981;136:719-27.

20 Dick R, Timmis B. Percutaneous needle biopsy of pulmonary tumours. In: Bates $\mathbf{M}$, ed. Bronchial carcinoma. An integrated approach to diagnosis and management. Berlin: Springer-Verlag, 1984:77-85.

21 Sheppard MN, Corrin B, Bloom SR, Polak JM. Lung endocrine tumours. In: Polak JM, Bloom SR, eds. Endocrine tumours. The pathology of regulatory peptide-producing tumours. Edinburgh: Churchill Livingstone, 1985:209-28.

22 Coleman DV, Russell WJI, Hodgson J, Tun PE, Mowbray JF. Human papovavirus in Papanicolaou smears of urinary sediment detected by transmission electron microscopy. J Clin Pathol 1977;30:1015-20.

23 Mennemeyer R, Hammar SP, Bauermeister DE, Whellis RF, Jones HW, Bartha M. Cytologic, histologic and electron microscopic correlations in poorly differentiated primary lung carcinoma. Acta Cytol (Baltimore) 1979;23:297-302.

24 Ghadially FN. Diagnostic electron microscopy of tumours. London: Butterworths, 1980.

25 Mackay B. Introduction to diagnostic electron microscopy. New York: Appleton-Century-Crofts, 1981.

26 World Health Organisation. Histological typing of lung tumours. 2nd ed. Geneva: WHO, 1981. (International Histological Classification of Tumours No 1.)

27 Wilson TS, McDowell EM, Marangos PJ, Trump BF. Histochemical studies of dense-core granulated tumours of the lung. Arch Pathol Lab Med 1985;109:613-20.

28 Wilson TS, McDowell EM, Trump BF. Immunohistochemical studies of keratin in human bronchus and lung tumours. Arch Pathol Lab Med 1985; 109:621-8.

29 Dunnill MS, Gatter KC. Cellular heterogeneity in lung cancer. Histopathology 1986;10:461-75.

$30 \mathrm{Kline}$ TS. Handbook of fine needle aspiration biopsy cytology. St Louis: C V Mosby, 1981.

31 Hajdu SI, Melamed MR. Limitations of aspiration cytology in the diagnosis of primary neoplasms. Acta Cytol (Baltimore) 1984;28:337-45. 